\title{
Kemampuan Pemecahan Masalah Matematika Melalui Pendekatan Pendidikan Matematika Realistik dan Pendekatan Penemuan Terbimbing Berbantuan Autograph
}

\author{
Weni Ariyanti Lubis ${ }^{1, a)}$, Suwarno Ariswoyo ${ }^{1}$, Edi Syahputra ${ }^{2}$ \\ ${ }^{1}$ Universitas Muslim Nusantara Al-Washliyah \\ Jl. Garu II A Harjosari I, Medan Amplas, Medan, Sumatera Utara, Indonesia, 20147 \\ ${ }^{2}$ Universitas Negeri Medan \\ Jl. Willem Iskandar Pasar V Kenangan Baru, Percut Sei Tuan, Deli Serdang, Indonesia, 20221 \\ ${ }^{a)}$ weniariyanti2309@gmail.com
}

\begin{abstract}
This study aims to examine the difference in Realistic Mathematics Education (RME) increase with students who obtain Autograph assisted discovery leaning, 2.The interaction between learning models and students initial mathematical abilities to students' mathematical problem solving abilities. This type of research is quasi-experimental. The population in this study were all the students of class IX SMA Alwashliyah 3 Medan totaling 90 students. The sample selection is determined by randomly selecting two classes. Instrument used in data collection consisted of tests of problem solving abilities, students' initial mathematical abilities and selfefficacy questionnaries. The results of the study indicate there are diffrences in the improvement of problem solving abilities provided by mathematics learning with the RME approach and Autograph Assisted Guided Discovery learning.
\end{abstract}

Keywords: discovery learning; problem solving; Realistic Mathematics Education

\begin{abstract}
Abstrak. Penelitian ini bertujuan untuk menelaah perbedaan peningkatan kemampuan pemecahan masalah matematika siswa yang memperoleh pendekatan Pendidikan Matematika Realistik (PMR) dengan siswa yang memperoleh pembelajaran penemuan terbimbing berbantuan Autograph. Jenis penelitian ini adalah quasi eksperimen. Populasi dalam penelitian ini adalah seluruh siswa kelas XI SMA Alwashliyah 3 Medan berjumlah 90 siswa. Pemilihan sampel penelitian ditentukan dengan cara acak memilih dua kelas. Instrumen yang digunakan dalam pengumpulan data terdiri dari tes kemampuan pemecahan masalah, kemampuan awal matematika siswa. Hasil penelitian menunjukkan terdapat perbedaan peningkatan kemampuan pemecahan masalah yang diberikan pembelajaran matematika dengan pendekatan PMR dan pembelajaran Penemuan Terbimbing berbantuan Autograph.
\end{abstract}

Kata Kunci: pemecahan masalah; Pendidikan Matematika Realistik; penemuan terbimbing 


\section{PENDAHULUAN}

Permendiknas No. 22 tahun 2006 tentang Standar Isi Mata Pelajaran Matematika menyatakan bahwa tujuan mata pelajaran matematika diajarkan di SMA yakni : 1. Memahami konsep matematika, menjelaskan keterkaitan antarkonsep dan mengaplikasikan konsep atau algoritma, secara luwes, akurat, efisien, dan tepat, dalam pemecahan masalah. 2. Menggunakan penalaran pada pola dan sifat, melakukan manipulasi matematika dalam membuat generalisasi, menyusun bukti, atau menjelaskan gagasan dan pernyataan matematika. 3. Memecahkan masalah yang meliputi kemampuan memahami masalah, merancang model matematika, menyelesaikan model dan menafsirkan solusi yang diperoleh. 4. Mengkomunikasikan gagasan dengan symbol, tabel, diagram, atau media lain untuk memperjelas keadaan atau masalah. 5. Memiliki sikap menghargai kegunaan matematika dalam kehidupan, yaitu memiliki rasa ingin tahu, perhatian, dan minat dalam mempelajari matematika, serta sikap ulet dan percaya diri dalam pemecahan masalah. Untuk mencapai kemampuan-kemampuan seperti yang disebutkan di atas, dibutuhkan pembelajaran yang mengacu pada pemberian kesempatan kepada siswa melakukan eksplorasi, menemukan, menganalisis dan mengumpulkan data.Oleh karena itu, siswa akan memiliki kesempatan mengembangkan kemampuan berfikirnya dalam menggambarkan dan memecahkan masalah baik itu masalah matematika maupun masalah yang ditemukannya dalam kehidupannya sehari-hari.

Hal ini sejalan dengan tujuan pembelajaran matematika yang dirumuskan oleh (NCTM, 2000) yaitu: 1) belajar untuk berkomunikasi (mathematical communication), 2) belajar untuk bernalar (mathematical reasoning), 3) belajar untuk memecahkan masalah (mathematical connection), 5) pembentukan sikap positif terhadap matematika (positive attitudes towards mathematics).Pada kenyataannya, pentingnya belajar matematika tidak sesuai dengan harapan, hal ini ditunjukkan dengan rendahnya nilai kemampuan matematika yang dapat dilihat dari hasil studi yang dilakukan oleh Programme for International Student Assesment (PISA). Menurut PISA (OECD, 2016) kemampuan matematika siswa-siswi Indonesia berada di peringkat 63 dari 69 negara atau dapat dikatakan peringkat ke enam dari bawah. Rendahnya prestasi matematika siswa salah satunya disebabkan oleh kurangnya kesempatan yang diberikan kepada siswa untuk menemukan dan melihat pola serta melakukan pemecahan masalah. Banyak guru memulai pembelajaran matematika dengan penjelasan tentang ide-ide yang terdapat pada halaman buku yang dipelajari, kemudian diikuti dengan menunjukkan kepada siswa bagaimana mengerjakan latihan soal. Bahkan ketika siswa berkegiatan, guru masih menuntun siswa bagaimana menggunakan materi yang dipelajari untuk mengerjakan latihan. Fokus utama dari pelajaran adalah mendapatkan jawaban. Para siswa menyandarkan kepada guru untuk menentukkan apakah jawabannya benar. Anak-anak yang mendapat pengalaman seperti ini akan mempunyai pandangan bahwa matematika adalah sederetan aturan yang tidak ada polanya yang dibawa oleh guru. 
Akibatnya anak-anak dijauhkan dari sumber pengetahuan yang sebenarnya dan tidak mampu memecahkan masalah tanpa bantuan dan campur tangan guru.

Hal tersebut terlihat dari observasi pembelajaran akan implementasi kurikulum 2013 yang belum diterapkan di SMA Alwashliyah 3 Medan kelas XI. Proses pembelajaran lebih menekankan latihan soal-soal rutin yang ada di buku teks pelajaran matematika SMA kelas XI. Pada saat pembelajaran, siswa sering berinteraksi dengan guru, akan tetapi interaksi yang berlangsung adalah pengecekan akan jawaban yang ditemukan siswa. Kegiatan tersebut selalu terjadi, dan hal ini semakin diperkuat oleh hasil jawaban siswa atas soal yang mengukur kemampuan pemecahan masalah pada materi transformasi pada soal berikut tuliskan yang diketahui dan ditanya: sebuah titik $(2,1)$ dicerminkan terhadap garis $\mathrm{y}=\mathrm{x}$ kemudian dicerminkan lagi terhadap garis $\mathrm{y}=5$. Gambarkanlah pada koodinat cartesius titik tersebut kemudian tentukanlah bayangan pencerminannya!
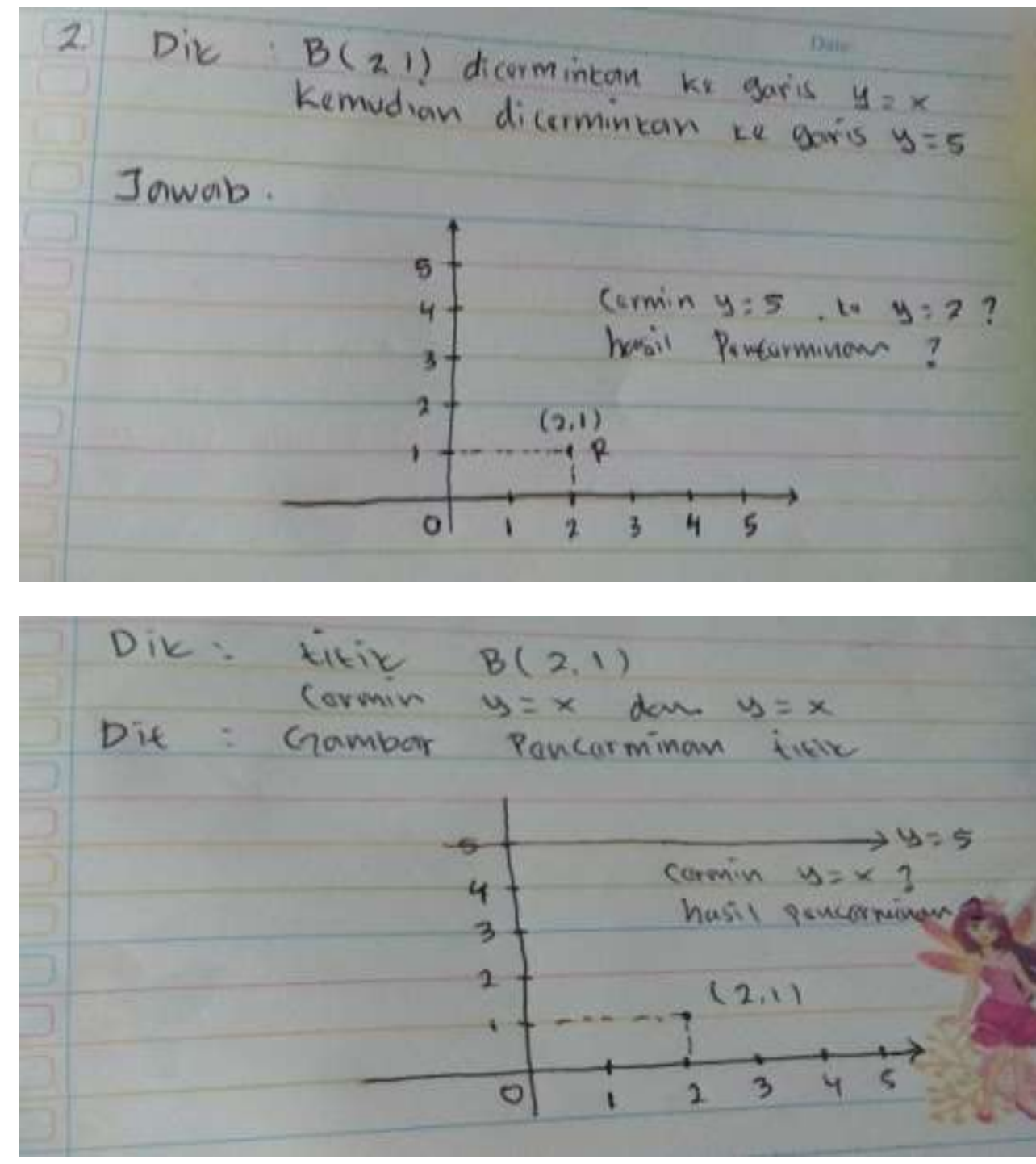

Gambar 1 Kesalahan siswa menyelesaikan soal pemecahan masalah 
Dari contoh jawaban tersebut, terlihat bahwa siswa tidak mampu menyelesaikan masalah matematika sesuai dengan prosedur penyelesaian masalah yaitu tidak memahami masalah, tidak merencanakan penyelesaiannya, tidak melaksanakan masalah sesuai rencana dan tidak melakukan pengecekan kembali terhadap semua langkah yang dikerjakan atau siswa kesulitan dalam menuangkan ide atau gagasan yang ditemukannya. Sementara, untuk menyelesaikannya harus mampu melihat hubungan antara konsep bilangan dan garis lurus tersebut.

Menurut Sternberg dan Ben-Zeev (Hasratuddin, 2018) menyatakan bahwa pemecahan masalah adalah suatu proses kognitif yang membuka peluang memecahkan masalah untuk bergerak dari suatu keadaan yang tidak diketahui bagaimana pemecahannya ke suatu keadaan tetapi tidak mengetahui bagaimana cara memecahkannya. Russefendi (Marhamah, Zulkardi, \& Aisyah, 2014) menyatakan, "kemampuan pemecahan masalah sangat penting dalam matematika, bukan saja bagi mereka yang kemudian hari akan mendalami atau mempelajari matematika, melainkan juga bagi mereka yang akan menerapkannya dalam bidang studi lain dan dalam kehidupan sehari-hari”. Dapat diketahui bahwa memecahkan masalah merupakan suatu bagian yang penting dalam matematika dan proses untuk mengembangkan kemampuan berpikir matematika siswa. Ketika siswa dihadapkan pada suatu masalah, maka siswa berusaha untuk menemukan solusinya. Siswa belajar menemukan bagaimana memecahkan soal tersebut untuk mendapatkan penyelesaiannya, mencari hubungan, menganalisis pola, menemukan metode mana yang sesuai dan yang tidak sesuai, menguji hasil dan menilai hasil dari pemikiran temannya (Gunawan \& Putra, 2019).

Menyikapi permasalahan yang timbul dalam pendidikan matematika sekolah tersebut, terutama yang berkaitan dengan pentingnya peningkatan kemampuan pemecahan masalah siswa diperlukan pendekatan pembelajaran yang dapat mengakomodai peningkatan- peningkatan kemampuan tersebut. Berbagai macam pendekatan yang dapat digunakan dalam upaya peningkatan kemampuan pemecahan masalah tersebut yaitu salah satu pendekatan pembelajaran yang dapat digunakan dan akan sejalan dengan karakteristik matematika adalah Pendekatan Matematika Realistik (Hadi, 2016). Pendekatan ini merupakan suatu pendekatan pembelajaran yang membawa peserta didik pada masalah nyata ( kontekstual), menggunakan model, menggunakan kontribusi siswa, interaktif, dan menggunakan keterkaitan (Dolk, 2006).

Menurut Ariawan \& Nufus (2017), matematika sekolah adalah matematika yang diajarkan di satuan pendidikan dengan materi matematika dan pola pikir yang disesuaikan dengan kebutuhan penerapan dalam kehidupan sehari-hari dan perkembangan ilmu pengetahuan. Pendidikan Matematika Realistik (PMR) adalah sebuah pendekatan belajar matematika yang dikembangkan sejak tahun 1971 oleh sekelompok ahli matematika dari Freudentha Institute, Utrecht University di Negeri Belanda. Pendekatan ini didasarkan pada pemikiran Hans Freudenthal (1905-1990) bahwa matematika adalah kegiatan manusia. Menurut pendekatan ini, kelas matematika bukan tempat 
memindahkan matematika dari guru kepada siswa, melainkan tempat siswa menemukan kembali ide dan konsep matematika melalui eksplorasi masalah-masalah realistis. Menurut Linusky \& Wijaya (2017), ketermaknaan konsep matematika merupakan konsep utama dari PMR. Proses pembelajaran siswa hanya akan terjadi jika pengetahuan yang dipelajari bermakna bagi siswa. Pembelajaran matematika dengan Pendekatan Matematika Realistik mempunyai ciri-ciri sebagai berikut: kontekstual, inventif, kreatif, berpikir alternative, komunikatif dan argumentative, koperatif dan demokratif. PMR bercirikan kontekstual karena bahan-bahan ajar diambil dari bahanbahan yang dekat, dikenal dan menarik perhatian siswa. Siswa ditantang untuk menyampaikan pemikirannya sedemikian rupa sehingga diharapkan dapat meyakinkan pendengar. Untuk itu, dilatih untuk mengungkapkan pemikiran atau gagasan secara urut, lengkap dan meyakinkan.

Selain Pendekatan Matematika Realistik (PMR), Pendekatan Penemuan Terbimbing juga diperlukan dalam pembelajaran matematika. Discovery merupakan bagian dari inquiry, atau inquiry merupakan perluasan proses discovery yang digunakan lebih mendalam. Inkuiri dalam bahasa Inggris inquiry, yang memiliki arti pertanyaan, pemeriksaan, dan penyelidikan. Dalam proses penemuan, siswa akan dibantu oleh guru atau pun hasil diskusi dengan temannya (Betyka, Putra, \& Erita, 2019). Penemuan juga dapat merupakan penemuan yang telah ditemukan orang lain (Putra \& Syarifuddin, 2019). Hosnan (2018) mengatakan bahwa "pembelajaran inquiry merupakan rangkaian kegiatan pembelajaran yang menekankan pada proses berpikir kritis dan analitis untuk mencari dan menemukan sendiri jawaban dari permasalahan yang ditanyakan”. Selanjutnya, penemuan terbimbing adalah satu pendekatan mengajar di mana guru memberi siswa contohcontoh topik spesifik dan memandu siswa untuk memahami topik tersebut.

Sedangkan menurut Wilcox (Kristin \& Rahayu, 2016) mengemukakan bahwa dalam belajar penemuan siswa didorong untuk terutama belajar sendiri melalui keterlibatan aktif dengan konsepkonsep dan prinsip-prinsip, dan guru mendorong siswa mempunyai pengalaman dan melakukan eksperimen yang memungkinkan mereka menemukan prinsip-prinsip bagi diri sendiri. Dari paparan di atas, dapat diketahui bahwa pembelajaran dengan menggunakan pendekatan penemuan terbimbing lebih menekankan kepada memanipulasi objek dan lain-lain percobaan, sebelum sampai pada generalisasi dimana siswa aktif terlibat didalamnya. Dengan kata lain, siswa sendiri atau kelompok secara aktif mencari informasi baru berdasarkan informasi yang diketahui sebelumnya dengan bimbingan guru.

Perkembangan pendidikan dalam kurikulum 2013 tidak terlepas dari perkembangan teknologi. Pada era globalisasi kemajuan teknologi semakin pesat, khususnya teknologi informasi dan komunikasi (ICT). Teknologi itu salah satunya yaitu computer. Komputer banyak digunakan pada berbagai bidang, teknik, astronomi, biologi, kesehatan, dan juga pendidikan. Pada dunia pendidikan sangat bermanfaat baik bagi guru maupun siswa. Komputer sangat mendukung baik 
pada kemampuan memahami matematika dalam belajar siswa khususnya soal matematika yang tidak biasa, artinya soal-soal matematika yang berhubungan dengan kehidupan sehari-hari. Siswa akan lebih semangat belajar matematika sehingga meningkatkan kemampuan pemecahan masalah matematika secara lebih baik menggunakan software komputer.

Beberapa penelitian telah menunjukkan dampak positif dari penggunaan software di sekolah. Menurut Erly (Simamora, 2018) bahwa hasil belajar siswa mengalami kenaikan setelah menggunakan modul "Mudahnya Geometri" sebagai bahan ajar berbasis ICT pada materi diferensial. Hal ini disebabkan karena dalam penggunaan Modul mudahnya Geometri ini disajikan lebih menarik dengan bantuan software matematika. Sehingga menambah menambah daya tarik dan semangat siswa dalam belajar. Oleh karena itu penggunaan software matematika memiliki pengaruh terhadap proses pembelajaran matematika, termasuk salah satunya software Autograph (Karnasih, 2008). Dengan menggunakan software ini diharapkan dapat membantu guru dalam membelajarkan matematika.

Karnasih (Afriati, 2012) bahwa Software Autograph adalah salah satu media yang dapat digunakan dalam mempelajari tentang dua dimensi, tiga dimensi, statistika, transformasi, geometri, persamaan, koordinat, differensial, grafik, aljabar dan lain-lain. Autograph akanmembantu siswa dalam melakukan percobaan yang baru. Siswa dapat menguji lebih banyak contoh-contoh dalam waktu singkat daripada menggunakan rumus, sehingga dari eksperimennya siswa dapat menemukan, mengkontruksi dan menyimpulkan prinsip-prinsip matematika, dan akhirnya memahami kemampuan matematika itu sendiri.

Berdasarkan uraian diatas maka diduga perbedaan peningkatan kemampuan pemecahan masalah dengan pendekatn PMR dan penemuan Terbimbing berbantuan Autograph mampu melatih kemampuan pemecahan masalah siswa. Belum terdapat penelitian tentang pendekatan PMR dan Penemuan Terbimbing berbantuan Autograph yang digunakan sebagai salah satu alternatif dalam pembelajaran Transformasi Geometri yang mungkin abstrak bagi siswa sehingga dapat mengaitkan materi tersebut dengan kehidupan sehari- hari dan juga dengan menemukan sendiri permasalahan yang sedang diberikan ke siswa dan menggunakan ICT sehingga pembelajaran tersebut lebih menarik. Oleh karena itu, peneliti akan melakukan penelitian tentang perbedaan peningkatan kemampuan pemecahan masalah matematika dengan pendekatan PMR dan penemuan Terbimbing berbantuan Autograph.

\section{METODE}

Penelitian ini dilaksanakan di SMA Alwashliyah 3 Medan . Objek penelitian ini adalah siswa kelas XI pada semester Genap Tahun Ajaran 2018/2019. Populasi dalam penelitian ini adalah seluruh siswa kelas XI SMA Alwashliyah 3 Medan TA. 2018/2019 yang terdiri dari 3 kelas paralel. 
EDUMATIKA: Jurnal Riset Pendidikan Matematika

e-ISSN 2620-8911

Volume 3, Nomor 1, Mei 2020

p-ISSN 2620-8903

Pemilihan sampel penelitian ditentukan dengan cara acak memilih dua kelas. Pemilihan secara acak digunakan dengan cara diundi yaitu kelas XI-1 sebanyak 30 siswa dan kelas XI-2 sebanyak 30 siswa.

Penelitian ini merupakan penelitian metode eksperimen semu (quasi eksperimen) dengan desain kelompok eksperimen 1 pretes dan posttest (prestest posttest control group design) (Arikunto, 2006). Pembelajaran dilaksanakan di kelas eksperimen 1 dengan pendekatan PMR dan kelas eksperimen dua dengan pendekatan penemuan Terbimbing. Sebelum pembelajaran dilakukan tes kemampuan awal untuk mengukur kemampuan awal pemecahan masalah siswa. Begitu pula dengan tes kemampuan akhir kemampuan pemecahan masalah matematika siswa pada saat setelah pembelajaran. Uji statistik yang digunakan pada penelitian ini adalah Uji Kolmogorov Sminorv Z untuk uji normalitas, Uji Levene's unuk uji homogenitas dan uji hipotesis menggunakan anava dua jalur.

\section{HASIL DAN PEMBAHASAN}

Berdasarkan hasi pretes dan postes kemampuan pemecahan masalah matematika siswa diperoleh data yang terlihat pada tabel 1. Berdasarkan hasil tersebut, rata- rata skor kemampuan pemecahan masalah pada kelas eksperimen satu dan dua naik sebanyak bahwa rata- rata pretes antara kelas eksperimen 1 dan kelas eksperimen 2 masing- masing adalah 53,67 dan 56,83. Rata - rata pretes kedua kelas terdapat perbedaan sebesar 3,16.

Tabel 1. Ringkasan Deskripsi Data Hasil Pretest dan Postest

\begin{tabular}{ccccc}
\hline \multirow{2}{*}{ Data Statistik } & \multicolumn{4}{c}{ Pembelajaran } \\
\cline { 2 - 5 } & \multicolumn{2}{c}{ Kelas Eksperimen 1 } & \multicolumn{2}{c}{ Kelas Eksperimen 2 } \\
\cline { 2 - 5 } & Pretes & Postes & Pretes & Postes \\
\hline $\bar{x}$ & 53,67 & 77,67 & 56,83 & 69,5 \\
\hline SD & 7,48 & 6,39 & 9,91 & 10,37 \\
\hline
\end{tabular}

Adapun peningkatan kemampuan pemecahan masalah matematika siswa dilihat dari hasil perhitungan n-gain pada kelas eksperimen 1 dan eksperimen 2, dan hasil perhitungan $n$ - gain pada kelas eksperimen 1 dan eksperimen 2 pada Table 2 berikut :

Tabel 2 Hasil perhitungan N- Gain Tes Kemampuan Pemecahan Masalah

\begin{tabular}{|c|c|c|c|}
\hline \multirow{2}{*}{ Indikator } & \multirow{2}{*}{ Data Statistik } & \multicolumn{2}{|c|}{ Pembelajaran } \\
\hline & & Kelas Eksperimen 1 & Kelas Eksperimen 2 \\
\hline \multirow{2}{*}{ Tinggi } & \multirow{2}{*}{ Rata-rata SD } & 0,73 & 0,75 \\
\hline & & 0,06 & 0,43 \\
\hline \multirow{2}{*}{ Sedang } & \multirow{2}{*}{ Rata- rata SD } & 0,45 & 0,40 \\
\hline & & 0,13 & 0,10 \\
\hline \multirow{2}{*}{ Rendah } & \multirow{2}{*}{ Rata- rata SD } & 0,15 & 0,16 \\
\hline & & 0,02 & 0,06 \\
\hline \multirow{2}{*}{ Keseluruhan } & \multirow{2}{*}{ Rata- rata SD } & 0,45 & 0,43 \\
\hline & & 0,07 & 0,20 \\
\hline
\end{tabular}


Berdasarkan Tabel 2, tampak secara keseluruhan bahwa rata- rata n-gain hasil tes kemampuan pemecahan masalah siswa pada kelas eksperimen 1 lebih tinggi daripada kelas eksperimen 2, yaitu 0,45>0,43. Tingginya rata-rata $n$-gain pada kelas eksperimen 1 dibandingkan kelas eksperimen 2 menunjukkan bahwa peningkatan kemampuan pemecahan masalah matematika siswa kelas eksperimen 1 lebih tinggi daripada peningkatan kemampuan pemecahan masalah matematika siswa eksperimen 2. Dengan demikian pemberian perlakuan dengan menggunakan pendekatan PMR memberikan peningkatan yang lebih baik dibandingkan pembelajaran dengan Penemuan Terbimbing.Pada kelas eksperimen 1 dan kelas eksperimen 2, siswa dengan KAM tinggi memperoleh rata-rata peningkatan kemampuan pemecahan masalah matematika ( N-Gain) yang lebih besar dari pada siswa dengan KAM sedang dan KAM rendah. Di samping itu, siswa pada kelas eksperimen 1 mendapatkan rata- rata peningkatan kemampuan pemecahan masalah matematika ( N-Gain) yang lebih besar daripada siswa dengan KAM sedang dan KAM rendah. Disamping itu, siswa pada kelas eksperimen 1 mendapatkan rata-rata peningkatan kemampuan pemecahan masalah matematika siswa (N-Gain) yang lebih besar daripada siswa kelas eksperimen 2 untuk setiap kategori KAM.

Uji prasyarat yang dilakukan adalah uji normalitas dan uji homogenitas. Uji normalitas digunakan untuk mengetahui apakah data berasal dari populasi yang berdistribusi normal atau tidak. Uji normalitas yang digunakan adalah uji Kolmogorov Smirnov Z. Diperoleh hasil pretest kemampuan Pemecahan masalah pada kelas eksperimen $1=0,083$ dan kelas eksperimen $2=0,056$. Sedangkanhasil Postest kemampuan pemecahan masalah pada kelas eksperimen $1=0,11$ dan kelas eksperimen $2=0,281$. Hasil tersebut menunjukkan bahwa nilai $p$-value lebih dari 0,05 sehingga disimpulkan bahwa semua data yang ada berasal dari populasi yang berdistribusi normal.

Selanjutnya hasil pengujian homogenitas digunakan untuk mengetahui apakah data memiliki variansi yang sama atau tidak. Uji homogenitas yang digunakan adalah Uji Levene's. Berdasarkan hasil tersebut dengan bantuan softwareSPSSdiperoleh hasil untuk data pretest nilai sig $=0,434$ dan Postest $=0,060$. Hasil tersebut menunjukan bahwa nilai $\mathrm{p}$ - value $>0,05$ sehingga disimpulkan bahwa data pretest dan postest kemampuan pemecahan masalah matematika siswa memiliki varians yang homogen (sama).

Selanjutnya Uji Hipotesis penelitian dilakukan dengan anava dua jalur menggunakan statistik f dengan rumus dan kriteria yang telah ditetapkan. Hasil perhitungan analisis uji hipotesis dengan bantuan program SPSS 20 dapat dilihat pada Tabel 3. 
EDUMATIKA: Jurnal Riset Pendidikan Matematika

e-ISSN 2620-8911

Volume 3, Nomor 1, Mei 2020

p-ISSN 2620-8903

Tabel 3 Hasil Analisis Anava Dua Jalur untuk Kemampuan Pemecahan Masalah

\begin{tabular}{cccccc}
\hline Source & Type III Sum of Squares & Df & Mean Square & F & Sig. \\
\hline Corrected Model & $1000.417^{\mathrm{a}}$ & 1 & 1000.417 & 13.481 & .001 \\
\hline Intercept & 324870.417 & 1 & 324870.417 & 4377.731 & .000 \\
\hline Kelas & 1000.417 & 1 & 1000.417 & 13.481 & .001 \\
\hline Error & 4304.167 & 58 & 74.210 & - & - \\
\hline Total & 330175.000 & 60 & - & - & - \\
\hline Corrected Total & 5304.583 & 59 & - & - & - \\
\hline
\end{tabular}

Berdasarkan Tabel 3 hasil analisis anava dua jalur untuk model pembelajaran faktor pembelajaran sebesar 0,001. Karena nilai probabilitas (sig) lebih kecil dari 0,05 sehingga disimpulkan terdapat perbedaan peningkatan kemampuan pemecahan masalah matematika siswa yang diajarkan dengan pendekatan PMR dan pembelajaran dengan Penemuan Terbimbing.

Hasil penelitian tersebut juga sejalan dengan penelitian sebelumnya yang dilakukan Islamiah dkk. (2018) dan Aisyah dkk. (2018) yang menyimpulkan bahwa kemampuan pemecahan masalah matematis siswa SMP mengalami peningkatan menggunakan metode inkuiri terbimbing daripada kemampuan pemecahan masalah siswa yang menggunakan pembelajaran biasa. Penelitian yang dilakukan sebelumnya juga yaitu penelitian Herlawan \& Hadija (2017) menyatakan peningkatan kemampuan pemecahan masalah matematis siswa yang mengikuti pembelajaran matematika dengan model creative problem solving berbasis kontekstual lebih baik dari pada siswa yang mengikuti pembelajaran dengan model konvensional. Hal ini senada dengan hasil penelitian dari Sumartini (2016). Dan juga penelitian yang dilakukan Sari, Habibi, \& Putri (2018) menyatakan model pembelajaran think pair share dapat meningkatkan pencapaian kemampuan pemecahan masalah matematis siswa yang menggunakan model pembelajaran TPS daripada yang mempeoleh pembelajaran biasa.

Untuk menguji interaksi antara pembelajaran dan KAM terhadap kemampuan pemecahan masalah matematika siswa digunakan anava dua jalur menggunakan statistik $\mathrm{F}$ dengan rumus dan kriteria yang telah ditetapkan. Hasil perhitungan analisis uji hipotesis dengan bantuan program SPSS 20 dapat dilihat pada Tabel 4 berikut :

Tabel 4 Hasil Analisis Anava Dua Jalur untuk Kemampuan Pemecahan Masalah

\begin{tabular}{c|c|c|c|c|c}
\hline Source & Type III Sum of Squares & df & Mean Square & F & Sig. \\
\hline Corrected Model & $4485.175^{\text {a }}$ & 5 & 897.035 & 69.217 & .000 \\
\hline Intercept & 75052.319 & 1 & 75052.319 & 5791.197 & .000 \\
\hline Kelas & 55.292 & 1 & 55.292 & 4.266 & .044 \\
\hline KAM & 3632.468 & 2 & 1816.234 & 140.144 & .000 \\
\hline Kelas * KAM & 5.961 & 2 & 2.980 & .230 & .795 \\
\hline Error & 699.825 & 54 & 12.960 & - & - \\
\hline Total & 183400.000 & 60 & - & - & - \\
\hline Corrected Total & 5185.000 & 59 & - & - & - \\
\hline
\end{tabular}


Berdasarkan Tabel 4 terlihat bahwa untuk faktor pembelajaran dan KAM, diperoleh nilai probabilitas (sig) sebesar 0,795. Karena nilai probabilitas (sig) lebih besar dari 0,05 ( 0,795 > 0,05) tidak terdapat interaksi antara pembelajaran KAM terhadap kemampuan pemecahan masalah matematika siswa. Ini menunjukkan bahwa tidak terdapat pengaruh secara bersama yang diberikan olehpembelajaran dan KAM. Lebih jelasnya, tidak terdapat interaksi antara pembelajaran dan kemampuan awal siswa terhadap peningkatan kemampuan pemecahan masalah matematika siswa. Interaksi tersebut dilihat pada Gambar 1.

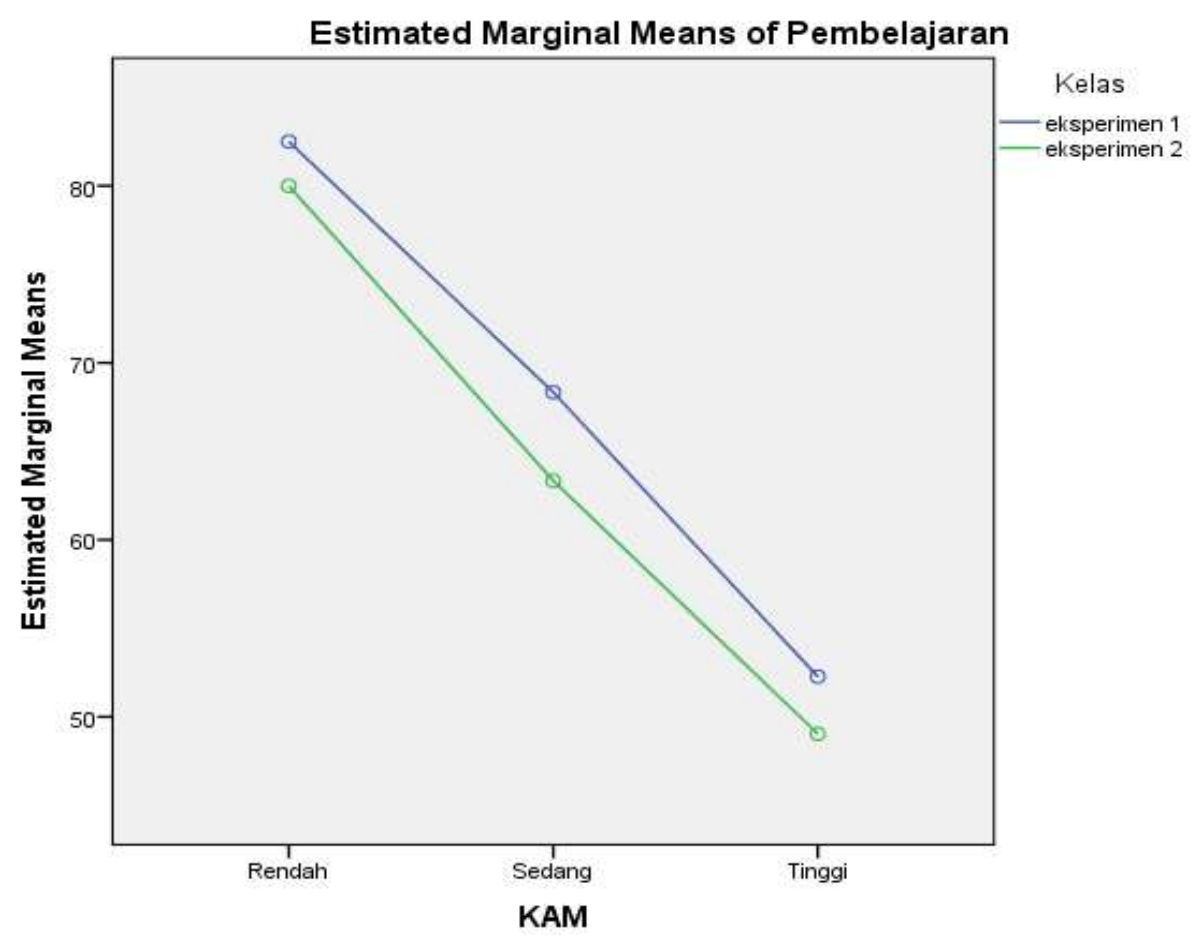

Gambar 2 Interaksi antara Pembelajaran dan KAM Terhadap Kemampuan Pemecahan Masalah Matematika Siswa

Diagram plot diatas berguna untuk menilai apakah ada interaksi efek antar variabel. Dari Gambar 1 di atas memperlihatkan bahwa garis kelas pembelajaran penemuan terbimbing tidak berpotongan dengan garis kelas pembelajaran Penemuan Terbimbing. Hal ini berarti tidak terdapat pengaruh secara bersama - sama yang disumbangkan oleh model pembelajaran dan KAM siswa terhadap kemampuan pemecahan masalah matematika siswa. sehingga disimpulkan bahwa tidak terdapat interaksi antara pembelajaran dan kemampuan awal matematika siswa terhadap kemampuan pemecahan masalah matematika siswa. Hasil ini sesuai dengan hasil penelitian dari Widyasari dan Rahmani (2018) bahwa tidak ada pengaruh yang signifikan antara KAM dengan media pembelajaran terhadap kemampuan pemecahan masalah. 


\section{SIMPULAN}

Berdasarkan hasil analisis, temuan dan pembahasan yang telah dikemukakan pada Bab sebelumnya diperoleh kesimpulan terdapat perbedaan peningkatan kemampuan pemecahan masalah matematika siswa yang diajarkan dengan Pendekatan PMR dan pembelajaran Penemuan Terbimbing berbantuan Autograph dan tidak terdapat interaksi antara pendekatan PMR dan kemampuan awal matematika siswa (tinggi, sedang, rendah) terhadap peningkatan kemampuan pemecahan masalah matematika siswa.

\section{SARAN}

Berdasarkan hasil-hasil dalam penelitian ini, peneliti mengemukakan beberapa rekomendasi terhadap penggunaan pembelajaran pendekatan PMR dalam proses pembelajaran matematika.

1. Penelitian ini menunjukkan bahwa pendekatan PMR dapat meningkatkan kemampuan pemecahan masalah matematika siswa. Dengan demikian, diharapkan dengan pembelajaran ini mampu meningkatkan kualitas pendidikan matematika.

2. Dalam penerapan pendekatan pembelajaran hendaknya memperhatikan penggunaan waktu dalam pembelajaran. Meskipun penggunaan konteks membutuhkan waktu yang lebih lama daripada pendekatan biasa, akan tetapi persiapan yang lebih matang akan membuat waktu yang digunakan lebih efektif dan efisien.

3. Lembar Aktivitas Siswa (LAS) sangat membantu dalam pelaksanaan proses pembelajaran. Akan tetapi peran aktif guru masih sangat diperlukan untuk membimbing siswa dalam mencapai tujuan pembelajaran. Dan hendaknya penyusunan LAS lebih memunculkan masalah yang menantang dan menarik namun dengan langkah-langkah sederhana sehingga siswa lebih menggali pengetahuan yang telah diperolehnya.

Mengubah cara pandang siswa terhadap matematika membutuhkan waktu yang cukup panjang, akan tetapi dengan adanya perubahan terhadap proses pembelajaran dari hari ke hari meuju yang lebih baik diharapkan dapat merubah ke arah positif dan dengan waktu yang lebih cepat.

\section{DAFTAR PUSTAKA}

Afriati, V. (2012). Peningkatan Pemahaman Konsep dan Komunikasi Matematik Siswa dengan Pendekatan Penemuan Terbimbing Berbantuan Software Autograph. Jurnal Paradikma, 5(1), 53-69.

Aisyah, P. N., Nurani, N., Akbar, P., \& Yuliani, A. (2018). Analisis Hubungan Kemampuan Pemecahan Masalah Matematis Dan Self Confidence Siswa SMP. Journal on Education, 1(1), 58-65.

Ariawan, R., \& Nufus, H. (2017). Hubungan Kemampuan Pemecahan Masalah Matematis dengan Kemampuan Komunikasi Matematis Siswa. Theorems (The Original Research of Mathematics), 1(2), 82-91. Retrieved from http://www.unma.ac.id/jurnal/index.php/th/article/view/384 
Arikunto, S. (2006). Prosedur Penelitian Suatu Pendekatan Praktik (Edisi IV). Jakarta: Rineka Cipta.

Dolk, M. (2006). Realistic Mathematics Education. Palembang.

Betyka, F., Putra, A., \& Erita, S. (2019). Pengembangan Lembar Aktivitas Siswa Berbasis Penemuan Terbimbing pada Materi Segitiga. JURING (Journal for Research in Mathematics Learning), 2(2), 179189.

Gunawan, R. G., \& Putra, A. (2019). Pengaruh Strategi Belajar Aktif Sortir Kartu Terhadap Kemampuan Pemecahan Masalah Matematis. Jurnal Cendekia: Jurnal Pendidikan Matematika, 3(2), 362-370.

Hadi, S. (2016). Pendidikan Matematika Realistik: Teori, Pengembangan dan Implementasinya. Jakarta: Rajawali Press.

Hasratuddin. (2018). Mengapa Harus Belajar Matematika. Medan: Perc. Edira.

Herlawan, H., \& Hadija, H. (2017). Peningkatan kemampuan pemecahan masalah matematis siswa kelas VII melalui penerapan model pembelajaran creative problem solving (CPS) berbasis kontekstual. JP3M (Jurnal Penelitian Pendidikan dan Pengajaran Matematika), 3(1), 33-38.

Hosnan, M. (2018). Pendekatan Santifik dan Kontekstual dalam Pembelajaran Abad 21 : Kunci Sukses Implementasi Kurikulum 2013. Bogor: Ghalia Indonesia.

Islamiah, N., Purwaningsih, W. E., Akbar, P., \& Bernard, M. (2018). Analisis Hubungan Kemampuan Pemecahan Masalah Matematis dan Self Confidence Siswa SMP. Journal on Education, 1(1), 47-57.

Karnasih, I. (2008). Paper Presented in International Workshop: ICT for Teaching and Learning Mathematics, Medan. Collaboration between UNIMED and QED Education Kuala Lumpur, Malaysia. Medan.

Kristin, F., \& Rahayu, D. (2016). Pengaruh Penerapan Model Pembelajaran Discovery Learning Terhadap Hasil Belajar Ips Pada Siswa Kelas 4 Sd. Scholaria: Jurnal Pendidikan Dan Kebudayaan, 6(1), 84.

Linnusky, I. N., \& Wijaya, A. (2017). Pengembangan Perangkat Pembelajaran dengan Pendekatan Pendidikan Matematika Realistik pada Materi Bangun Ruang Sisi Datar Kelas VIII SMP / MTs. Jurnal Pendidikan Matematika, 6(1), 1-9.

Marhamah, M., Zulkardi, Z., \& Aisyah, N. (2014). Pengembangan Materi Ajar Pecahan Dengan Pendekatan Pmri Di Sd Negeri 21 Palembang. Jurnal Pendidikan Matematika, 5(2), 171-184. https://doi.org/10.22342/jpm.5.2.584.

NCTM. (2000). Standards for school Mathematics. Retrieved from NCTM website: https://www.nctm.org/Standards-and-Positions/Principles-and-Standards/

OECD. (2016). Singapore tops latest OECD PISA global education survey. Retrieved from Oecd website: http://www.oecd.org/education/singapore-tops-latest-oecd-pisa-global-education-survey.htm

Putra, A., \& Syarifuddin, H. (2019). Analisis Kebutuhan Pengembangan Lembar Kerja Siswa Berbasis Penemuan Terbimbing Kelas VIII Sekolah Menengah Pertama. Jurnal Edukasi Matematika Dan Sains, 6(1), 39-49.

Sari, M., Habibi, M., \& Putri, R. (2018). Pengaruh Model Pembelajaran Kooperatif Tipe Think-Pairs-Share Dalam Pembelajaran Matematika Terhadap Kemampuan Pemahaman Konsep Matematis dan Pengembangan Karakter Siswa SMA Kota Sungai Penuh. Edumatika: Jurnal Riset Pendidikan Matematika, 1(1), 7-21.

Simamora, R. U. (2018). Perbedaan Kemampuan Komunikasi Mathematis Dan Self-Efficay Siswa Yang Diberi Pembelajaran Matematika Dengan Pendekatan Matematika Realistik (PMR) Dan Pembelajaran Berbasis Masalah (PBM) Dengan Berbantuan Autograph. Universitas Negeri Medan.

Sumartini, T. S. (2016). Peningkatan kemampuan pemecahan masalah matematis siswa melalui pembelajaran berbasis masalah. Mosharafa: Jurnal Pendidikan Matematika, 5(2), 148-158.

Widyasari, N., \& Rahmani, W. (2018, July). Interaksi Kemampuan Awal Matematika Dengan Media Pembelajaran Tangram Terhadap Kemampuan Pemecahan Masalah Matematis Siswa. In Prosiding Seminar Nasional Pendidikan, 1(1). 